\title{
PENGARUH TEKNIK PERNAFASAN BUTEYKO TERHADAP PENURUNAN FREKUENSI KEKAMBUHAN ASMA PADA PASIEN PENDERITA ASMA
}

\author{
Irfah Baroroh, Hermansyah, Septiyanti \\ Politeknik Kesehatan Kementerian Kesehatan Bengkulu, Program Studi D-IV Keperawatan, \\ Jalan Indragiri Nomor 03 Padang Harapan Kota Bengkulu \\ queen_leopard@yahoo.com
}

\begin{abstract}
Asthma is a disease that is very close to the community and has an ever-increasing population. The prevalence of asthma in Indonesia is $3.5 \%$. Prevalence of asthma in Bengkulu, especially Rejang Lebong in 2012 amount 1.606 people. Higher data in Kampung Delima Working Area Health Center are 182 peoples and theres 53 people $(29,12 \%)$ feels recurrence. This study aimed to determine the effect of buteyko breathing techniques to decrease the frequency of recurrence of asthma in asthmatics in Kampung Delima Working Area Health Center. This study was pre Experimental design using one group pre and post test. Populations of this study are 182 people. The samples were taken with accidental sampling technique which amounts to 30 people. The distribution of the average frequency of recurrence of asthma before being given Buteyko breathing technique is 3.40 and the average frequency after the Buteyko breathing technique given is 2.07 . Based on the analysis of test data is obtained, which means there is the influence of the Buteyko breathing technique to decrease the frequency of recurrence of asthma in the Work Area Kampung Delima health center $(\mathrm{p}=0,000)$.
\end{abstract}

\section{Keywords : Buteyko Breathing Technique, Recurrence Asthma}

\begin{abstract}
Abstrak: Asma merupakan penyakit yang sangat dekat dengan masyarakat dan mempunyai populasi yang terus meningkat. Prevalensi asma di Indonesia adalah 3,5\%. Angka kejadian asma di Provinsi Bengkulu, khususnya Kabupaten Rejang Lebong pada tahun 2012 sebanyak 1.606 orang. Data tertinggi terletak di Puskesmas Kampung Delima yaitu 182 orang terdapat 53 orang $(29,12 \%)$ yang mengalami kekambuhan. Penelitian ini bertujuan untuk mengetahui pengaruh teknik pernafasan buteyko terhadap penurunan frekuensi kekambuhan asma pada penderita asma di Wilayah Kerja Puskesmas Kampung Delima Tahun 2013. Penelitian ini adalah Pre Experimental dengan menggunakan rancangan one group pre and post test. Jumlah populasi adalah 182 orang. Pengambilan sampel menggunakan teknik accidental sampling dengan jumlah sampel 30 orang. Distribusi rata-rata frekuensi kekambuhan asma sebelum diberikan teknik pernafasan buteyko adalah 3,40 dan rata-rata frekuensi sesudah diberikan teknik pernafasan buteyko adalah 2,07. Berdasarkan hasil analisis data ada pengaruh teknik pernafasan buteyko terhadap penurunan frekuensi kekambuhan asma pada penderita asma di Wilayah Kerja Puskesma Kampung Delima ( $\mathrm{p}=0,000)$.
\end{abstract}

Kata Kunci: Teknik Pernafasan Buteyko, Kekambuhan Asma

Asma adalah penyakit inflamasi kronik saluran nafas yang menyebabkan peningkatan hiperresponsif yang menimbulkan gejala episodik berulang berupa mengi,sesak nafas, batuk-batuk, terutama malam menjelang dini hari (PDPI, 2006). Asma termasuk dalam sepuluh besar penyebab kesakitan dan kematian di Indonesia, hasil sementara pilot PAL
(Practical Approach on Lung Health) Tahun 2012 di Propinsi DKI Jakarta jumlah kasus baru asma 1194 dan kasus serangan ulang 301; Jawa Barat kasus baru 2039 dan kasus serangan ulang 762; dan Lampung menunjukkan jumlah kasus baru asma 953, kasus serangan ulang 558. Berdasarkan data Sistem Informasi Rumah Sakit (SIRS) di Indonesia 
didapatkan bahwa angka kematian akibat penyakit asma adalah sebanyak 63.584 orang. Data Riskesdas 2007 menyatakan bahwa prevalensi asma di Indonesia adalah 3,5\%. Secara nasional, 10 kabupaten/kota dengan prevalensi Penyakit Asma tertinggi adalah Aceh Barat (13,6\%), Buol (13,5\%), Pohuwato (13,0\%), Sumba Barat $(11,5 \%)$, Boalemo (11,0\%), Sorong Selatan $(10,6 \%)$, Kaimana (10,5\%), Tana Toraja $(9,5 \%)$, Banjar (9,2\%), dan Manggarai (9,2\%).

Angka kejadian asma di Provinsi Bengkulu, khususnya Kabupaten Rejang Lebong pada tahun 2010 sebanyak 1.353 orang, tahun 2011 sebanyak 1.499 . orang dan tahun 2012 sebanyak 1.606 orang. Dari 4 puskesmas yang berada di Kabupaten Rejang Lebong pada tahun 2012, Puskesmas Kampung Delima memiliki angka tertinggi yaitu 182 orang kemudian diikuti oleh puskesmas Sambirejo 179 orang, puskesmas Talang Ulu 154 orang, puskesmas Curup 143 orang. (Profil Dinkes Rejang Lebong, 2012). Menurut laporan data kesakitan (LB1) dari Puskesmas Kampung Delima dari tahun 2010-2012 menunjukkan banyaknya pasien dengan diagnosis asma sebanyak 154 orang pada tahun 2010, 161 orang pada tahun 2011 dan 182 orang pada tahun 2012. Penelitian oleh Wahyuni (2012) tentang faktor risiko yang berpengaruh terhadap tingkat kekambuhan asma di wilayah kerja Puskesmas Kampung Delima menyebutkan dari 182 responden terdapat 53 responden $(29,12 \%)$ yang mengalami kekambuhan.

Asma dapat menyebabkan terganggunya pemenuhan kebutuhan dan menurunkan produktivitas penderitanya (PDPI, 2006). Dalam sebuah studi suatu kasus ditemukan bahwa dari 3.207 kasus yang diteliti, penderita yang mengaku mengalami keterbatasan dalam berekreasi atau olahraga sebanyak $52,7 \%, 44-51 \%$ mengalami batuk malam dalam sebulan terakhir, keterbatasan dalam aktivitas fisik sebanyak 44,1\%, keterbatasan dalam aktivitas sosial sebanyak $38 \%$, keterbatasan dalam memilih karier sebanyak $37,9 \%$, dan keterbatasan dalam cara hidup sebanyak $37,1 \%$. Bahkan, penderita yang mengaku mengalami keterbatasan dalam melakukan pekerjaan rumah tangga sebanyak $32,6 \%, 28,3 \%$ mengaku terganggu tidurnya minimal sekali dalam seminggu, dan $26,5 \%$ orang dewasa juga absen dari pekerjaan.

Asma dapat dikendalikan dengan cara pengelolaan yang dilakukan secara lengkap, tidak hanya dengan pemberian terapi farmakologis tetapi juga menggunakan terapi nonfarmakologis yaitu dengan cara mengontrol gejala asma. Pengontrolan terhadap gejala asma dapat dilakukan dengan cara menghindari alergen pencetus asma, konsultasi asma dengan tim medis secara teratur, hidup sehat dengan asupan nutrisi yang memadai, dan menghindari stres (Wong, 2003).

Akhir-akhir ini, para penderita asma mulai memanfaatkan terapi komplementer (nonfarmakologis) untuk mengendalikan asma yang dideritanya. Jumlah penderita asma yang sudah memanfaatkan terapi komplementer ini diperkirakan cukup tinggi yaitu sekitar 42 persen dari populasi penderita asma yang ada di New Zealand (McHugh, 2003). Pengontrolan asma dengan terapi komplementer dapat dilakukan dengan teknik pernapasan, teknik relaksasi, akupunktur, chiropractic, homoeopati, naturopati dan hipnosis. Teknik-teknik seperti ini merupakan teknik yang banyak dikembangkan oleh para ahli. Salah satu teknik yang banyak digunakan dan mulai populer adalah teknik pernapasan.

Salah satu metode yang dikembangkan untuk memperbaiki cara bernapas pada penderita asma adalah teknik olah napas. Teknik olah napas ini dapat berupa olahraga aerobik, senam, dan teknik pernapasan seperti Thai chi, Waitankung, Yoga, Mahatma, Buteyko, dan Pranayama (Fadhil, 2009). Teknik pernapasan buteyko merupakan salah satu teknik olah napas yang bertujuan untuk menurunkan ventilasi alveolar terhadap hiperventilasi paru (GINA, 2005). Pada asma, gejala yang sering terjadi adalah hiperventilasi atau bernapas dalam Hiperventilasi terjadi karena penderita asma mengembangkan tingkat kedalaman pernapasan jauh melebihi yang seharusnya. Hasil penelitian oleh Zara (2012), tentang efektivitas senam per- 
nafasan buteyko terhadap gejala asma di Kecamatan Bayang Painan Pesisir Selatan menunjukkan terdapat pengaruh yang bermakna pada pemberian teknik pernapasan buteyko terhadap penurunan gejala asma.

Metode pernafasan buteyko kurang begitu dikenal dikalangan masyarakat Indonesia. Terapi pernapasan yang telah dikembangkan di Indonesia dikenal sebagai Senam Asma Indonesia yang terdiri dari beberapa tahapan latihan seperti halnya olah raga yang lain, yaitu: pemanasan, latihan inti A, latihan inti $\mathrm{B}$, aerobik dan pendinginan. Padahal disebutkan bahwa metode ini cukup efektif mengendalikan serangan asma. Berdasarkan uraian diatas perlu dianalisis pengaruh teknik pernafasan buteyko terhadap penurunan frekuensi kekambuhan asma pada penderita asma di Wilayah Kerja Puskesmas Kampung Delima. Penelitian ini bertujuan untuk untuk mengetahui pengaruh teknik pernafasan buteyko terhadap penurunan frekuensi kekambuhan asma pada penderita asma di Wilayah Kerja Puskesmas Kampung Delima.

\section{BAHAN DAN CARA KERJA}

Penelitian ini adalah Pre Experimental dengan menggunakan rancangan one group pre and post test. Populasi dalam penelitian ini adalah seluruh pasien asma di Puskesmas Kampung Delima pada tahun 2013 dengan estimasi pasien asma pada tahun 2012 yaitu berjumlah 182 orang. Dalam penelitian ini teknik yang digunakan untuk mengambil sampel yaitu accidental sampling dengan jumlah sampel 30 orang. Penelitian ini menggunakan lembar observasi mengukur frekuensi kekambuhan asma sebelum dan sesudah intervensi. Prosedur pengumpulan data pada penelitian ini dengan cara menjelaskan tujuan, manfaat, prosedur pengumpulan data dan meminta persetujuan calon responden selanjutnya dilakukan pengisian lembar observasi awal tentang frekuensi kekambuhan asma sebelum tindakan teknik pernafasan buteyko. Selanjutnya memberikan prosedur teknik pernafasan buteyko dan mendemontrasikan teknik pernafasan buteyko kepada responden Res- ponden diminta untuk mengulangi teknik pernafasan buteyko sebanyak dua kali. Teknik pernafasan buteyko ini dilakukan setiap harinya selama satu bulan dengan diobservasi oleh peneliti setiap minggunya untuk mengetahui frekuensi kekambuhan asma responden.

\section{HASIL}

\section{Analisis Univariat}

Tabel 1. Distribusi Rata-Rata Frekuensi Kekambuhan Asma Sebelum dan Sesudah Dilakukan Teknik Pernafasan Buteyko

\begin{tabular}{cccccc}
\hline Variabel & $\mathbf{N}$ & $\begin{array}{c}\text { Mean } \\
\text { Median }\end{array}$ & SD & $\begin{array}{c}\text { Min } \\
\text { Max }\end{array}$ & 95\% CI \\
\hline Pre & 30 & 3,40 & 1,303 & 1 & $2,91-3,89$ \\
& & 3,00 & & 6 & \\
\hline Post & 30 & 2,07 & 1,202 & 0 & $1,62-2,52$ \\
& & 2,00 & & 5 & \\
\hline
\end{tabular}

Tabel 1 hasil analisis univariat menunjukkan nilai mean, nilai minimal, standar deviasi dan $95 \%$ CI of mean sebelum dan sesudah dilakukan intervensi (teknik pernafasan buteyko). Hasil analisis menunjukkan ratarata frekuensi kekambuhan asma sebelum diberikan intervensi teknik pernafasan buteyko adalah 3,40 dan standar deviasi 1,303. Frekuensi kekambuhan asma terendah adalah 1 dan tertinggi adalah 6. Dari hasil estimasi interval dapat disimpulkan bahwa 95\% diyakini rata-rata frekuensi kekambuhan asma sebelum diberikan intervensi teknik pernafasan buteyko adalah antara 2,91 sampai dengan 3,89. Sedangkan untuk rata-rata frekuensi kekambuhan asma sesudah diberikan intervensi teknik pernafasan buteyko adalah 2,07 dan standar deviasi 1,202. Frekuensi kekambuhan asma terendah adalah 0 dan tertinggi adalah 5. Dari hasil estimasi interval dapat disimpulkan bahwa $95 \%$ diyakini rata-rata frekuensi kekambuhan asma sesudah diberikan intervensi teknik pernafasan buteyko adalah antara 1,62 sampai dengan 2,52.

\section{Analisis Bivariat}

Analisis ini dilakukan untuk mengetahui adanya penurunan frekuensi kekambuhan asma sebelum dan sesudah teknik pernafasan buteyko. Untuk melihat perbedaan 
penurunan frekuensi kekambuhan asma dilakukan uji Paired t-test.

Tabel 2. Distribusi Rata-Rata Frekuensi Kekambuhan Asma Sebelum dan Sesudah Dilakukan Teknik Pernafasan Buteyko

\begin{tabular}{ccccccc}
\hline F & N & Mean & SD & SE & $\begin{array}{c}\text { T } \\
(\mathbf{d f})\end{array}$ & $\begin{array}{c}\mathbf{P} \\
\text { value }\end{array}$ \\
\hline Pre & 30 & 3,40 & 1,303 & 0,238 & $\begin{array}{c}11,050 \\
(29)\end{array}$ & 0,000 \\
Post & 30 & 2,07 & 1,202 & 0,219 & & \\
\hline
\end{tabular}

Hasil uji statistik menunjukkan nilai $\mathrm{p}=0,000<\alpha 5 \%$ (one tail) artinya ada penurunan rata-rata frekuensi kekambuhan asma sesudah dilakukan teknik pernafasan buteyko dibandingkan rata-rata frekuensi kekambuhan asma sebelum dilakukan teknik pernafasan buteyko. Dapat disimpulkan ada pengaruh teknik pernafasan buteyko terhadap penurunan frekuensi kekambuhan asma.

\section{PEMBAHASAN}

\section{Gambaran Frekuensi Kekambuhan Asma}

Puskesmas Kampung Delima merupakan Puskesmas dengan angka kejadian asma tertinggi diantara 4 puskesmas lainnya di Kabupaten Rejang Lebong. Angka kejadian asma dalam tahun 2012 di Puskesmas Kampung Delima adalah 182 orang dan terdapat 53 orang yang rutin berobat ke Puskesmas. Dalam penelitian ini dari 53 responden yang mengalami kekambuhan asma diambil 30 responden dan kemudian diukur frekuensi rata-rata kekambuhannya selama 1 bulan terakhir yaitu 3,40 ( 95\% CI : 2,91-3,89).

Hasil penelitian ini sejalan dengan penelitian oleh Yoana (2009) tentang efektifitas teknik pernafasan buteyko terhadap penurunan tingkat kekambuhan asma pada penderita asma di Kecamatan Munibau Riau menunjukkan dari 40 responden rata-rata kekambuhan asma selama 1 bulan terakhir adalah 3,78. Penelitian lain yang dilakukan oleh Zara (2012) tentang efektivitas senam pernafasan buteyko terhadap gejala asma di Kecamatan Bayang Painan Pesisir Selatan menunjukkan nilai rata-rata gejala asma sebelum dilakukan teknik pernafasan buteyko adalah
3,18 . Pemicu tingginya angka kekambuhan asma di wilayah Puskesmas Kampung Delima ini adalah faktor cuaca yang dingin dan faktor pendukung lainnya seperti asap rokok dan debu. Hal ini selaras dengan penelitian oleh Wahyuni (2012) tentang faktor risiko yang berpengaruh terhadap tingkat kekambuhan asma di wilayah kerja Puskesmas Kampung Delima menyebutkan bahwa faktor cuaca, faktor asap rokok, faktor gangguan emosi, faktor infeksi saluran pernafasan dan faktor olahraga mempengaruhi kekambuhan asma responden dan dari 182 responden terdapat 53 responden $(29,12 \%)$ yang mengalami kekambuhan asma.

\section{Pengaruh Teknik Pernafasan Buteyko Ter- hadap Penurunan Frekuensi Kekambuhan Asma}

Hasil penelitian menunjukkan bahwa terjadi perbedaan rata-rata frekuensi kekambuhan asma sebelum dan sesudah dilakukan teknik pernafasan buteyko. Frekuensi kekambuhan asma sebelum dan sesudah intervensi secara umum mengalami penurunan, yang berarti ada pengaruh teknik pernafasan buteyko terhadap penurunan frekuensi kekambuhan asma pada responden $(\mathrm{p}=0,000)$.

Dari uraian diatas dapat dilihat perkembangan penurunan frekuensi kekambuhan asma pada penderita asma setelah dilakukan teknik pernapasan Buteyko. Sesuai dengan pendapat Dupler (2005) bahwa gejala asma dapat dikurangi dengan melakukan teknik dan olah pernapasan secara teratur. Selain itu, dengan melakukan teknik pernapasan Buteyko maka peningkatan kadar karbondioksida dapat tercapai sehingga terjadi dilatasi otot bronkus yang kemudian mengurangi bronkospasme dan munculnya wheezing dan pada akhirnya akan mengurangi frekuensi kekambuhan (Mchugh et al., 2003).

Hasil penelitian ini juga sesuai dengan penelitian oleh Yoana (2009) tentang efektifitas teknik pernafasan buteyko terhadap penurunan tingkat kekambuhan asma pada penderita asma di Kecamatan Munibau Riau yang menunjukkan bahwa teknik pernafasan buteyko efektif terhadap penurunan tingkat kekambuhan asma pada penderita asma 
$(\mathrm{p}=0,002)$. Penelitian lain oleh Zara (2012), tentang efektivitas senam pernafasan buteyko terhadap gejala asma di Kecamatan Bayang Painan Pesisir Selatan menunjukkan terdapat pengaruh yang bermakna pada pemberian teknik pernapasan buteyko terhadap penurunan gejala asma.

Menurut Fadhil (2009), teknik olah napas bermanfaat untuk mengurangi gejala asma secara kausatif yaitu dengan memperbaiki cara dan pola bernapas yang benar. Teknik pernapasan Buteyko mengurangi hiperventilasi secara bertahap selama latihan teratur, sehingga dapat meningkatkan kadar karbondioksida di dalam darah yang kemudian akan menjaga keseimbangan $\mathrm{pH}$ darah melalui pembentukan asam karbonat dan bikarbonat, mengurangi ekspirasi paksa serta penekanan pada otot dinding dada yang menyebabkan rasa sesak (Dupler, 2005).

Teknik pernapasan Buteyko juga melatih cara bernapas yang efektif dan efisien dengan mengandalkan otot diafragma sebagai otot pernapasan utama (Dupler, 2005). Teknik pernapasan Buteyko juga melatih kemampuan menahan napas dengan menggunakan pernapasan diafragma, cara ini diharapkan dapat mengoptimalkan penggunaan paru, dengan cara demikian karbondioksida yang hilang akibat hiperventilasi dapat terperangkap di dalam darah. Pendapat yang sama dinyatakan oleh Hoeman dalam Mardhiah (2009) bahwa pernapasan melalui penggunaan pergerakan diafragma lebih baik dari pada menggunakan otot pernapasan yang lainnya seperti otot asesoris pernapasan. Dengan demikian dapat mengurangi beban kerja saat bernapas, sehingga perasaan sesak dapat berkurang.

Teknik pernapasan dapat menurunkan gejala asma jika dilakukan dengan teratur. Teknik pernapasan Buteyko juga membantu menyeimbangkan kadar karbondioksida dalam darah sehingga pergeseran kurva disosiasi oksihemoglobin yang menghambat ke- lancaran oksigenasi dan efek Bohr pada penderita asma dapat dikurangi. Teknik pernapasan Buteyko juga melatih cara bernapas yang efektif dan efisien dengan mengandalkan otot diafragma sebagai otot pernapasan utama untuk memperkuat otot-otot pernapasan selama latiahan menahan napas. Oleh karena prinsip teknik pernapasan $\mathrm{Bu}-$ teyko adalah untuk merilekskan otot pernapasan dan iga secara perlahan-lahan, maka rasa tertekan di dada secara bertahap juga dapat berkurang (Dupler, 2005).

\section{KESIMPULAN}

Terdapat penurunan prekuensi kekambuhan asma pada penderita asma dibuktikan oleh distribusi rata-rata frekuensi kekambuhan asma sebelum diberikan teknik pernafasan buteyko adalah 3,40 dan rata-rata frekuensi sesudah diberikan teknik pernafasan buteyko adalah 2,07, sehingga dapat disimpulkan ada pengaruh teknik pernafasan buteyko terhadap penurunan frekuensi kekambuhan asma di wilayah kerja Puskesmas Kampung Delima $(p=0,000)$. Saran bagi tenaga pelayanan kesehatan di Puskesmas Kampung Delima diharapkan dapat melakukan sosialisasi mengenai teknik pernafasan buteyko dan selanjutnya dilakukan pelatihan teknik pernapasan buteyko pada staf keperawatan sehingga dapat dipraktekkan dalam intervensi keperawatan sebagai upaya peningkatan derajat kesehatan pasien asma. Bagi penderita asma diharapkan untuk mempraktekkan teknik pernafasan buteyko sebagai salah satu cara untuk pengendalian kekambuhan asma. Untuk Poltekkes Kemenkes Bengkulu teknik pernafasan butyko ini tidak hanya dapat menambah variasi ilmu pengetahuan tetapi juga dimasukkan dalam salah satu mata kuliah KMMB sehingga dilakukan simulasi, tutorial serta praktek mandiri teknik pernapasan buteyko sebagai salah satu cara penanganan kekambuhan asma.

\section{DAFTAR RUJUKAN}


Fadhil. 2009. Teknik Pengolahan Nafas, Diakses pada tanggal 2 oktober 2013 dari http://www.wikipedia.com/teknik_pengolahan_ nafas.html.

Global Initiative for Asthma (GINA). 2005. Global Strategy for Asthma Management and Prevention, Diakses pada tanggal 7 September 2013 dari http://www.ginasthma.com/GuidelineItem.asp? intId $=1170$.

Mardhiah. 2009. Efektivitas Olahraga Pernapasan Terhadap Penurunan Gejala Asma Pada Penderita Asma Di Lembaga Seni Pernapasan Satria Nusantara Cabang Medan, Medan : Fakultas Keperawatan Universitas Sumatera Utara.

McHugh, P., Aitcheson, F., Duncan, B. \& Houghton, F. 2003. Buteyko Breathing Technique for asthma: an effective intervention, Diakses pada tanggal 7 Januari 2014 dari http://www.nzma.org.nz/journal/vacancies.html

Perhimpunan Dokter Paru Indonesia. 2006. ASMA Pedoman Diagnosis dan Penatalaksanaan di
Indonesia, Jakarta : Perhimpunan Dokter Paru Indonesia.

Purnomo. 2008. Faktor faktor risiko yang berpengaruh terhadap kejadian asma di RS Kabupaten Kudus, Jakarta: Universitas Indonesia

Wahyuni. 2012. Faktor risiko yang berpengaruh terhadap tingkat kekambuhan asma di wilayah kerja Puskesmas Kampung Delima, Bengkulu : Poltekkes Kemenkes Bengkulu.

Wong. 2003. Essentials of Nursing ResearchMethods, Appraise and Utilization, Philadelphia : Lippincott Williams \& Wilkins.

Yoana. 2009. Efektifitas teknik pernafasan buteyko terhadap penurunan tingkat kekambuhan asma pada penderita asma di Kecamatan Munibau Riau, Riau : Universitas Riau

Zara. 2012. Efektivitas senam pernafasan buteyko terhadap gejala asma di Kecamatan Bayang Painan Pesisir, Padang : Universitas Padjajaran. 